\title{
The impact of antibiotics on growth in children in low and middle income countries: systematic review and meta-analysis of randomised controlled trials
}

\begin{abstract}
Ethan K Gough PhD candidate ${ }^{1}$, Erica E M Moodie associate professor ${ }^{1}$, Andrew J Prendergast associate professor and clinical senior lecturer ${ }^{234}$, Sarasa M A Johnson Mph candidate ${ }^{1}$, Jean $\mathrm{H}$ Humphrey director and professor ${ }^{25}$, Rebecca J Stoltzfus professor and director ${ }^{6}$, A Sarah Walker senior statistician ${ }^{4}$, Indi Trehan assistant professor and visiting lecturer in paediatrics and child health ${ }^{78}$, Diana M Gibb professor and paediatric programme of trials programme leader ${ }^{4}$, Rie Goto affiliated lecturer ${ }^{9}$, Soraia Tahan professor ${ }^{10}$, Mauro Batista de Morais chief of paediatrics ${ }^{10}$, Amee R Manges associate professor ${ }^{11}$
\end{abstract}

\begin{abstract}
${ }^{1}$ Department of Epidemiology, Biostatistics and Occupational Health, McGill University, Montreal, QC, Canada; ${ }^{2} Z$ vitambo Institute for Maternal Child Health Research, Harare, Zimbabwe; ${ }^{3}$ Centre for Paediatrics, Blizard Institute, Queen Mary University of London, UK; ${ }^{4}$ Medical Research Council Clinical Trials Unit, London, UK; ${ }^{5}$ Department of International Health, Johns Hopkins Bloomberg School of Public Health, Baltimore, MD, USA; ${ }^{6}$ Division of Nutritional Sciences, Program in International Nutrition, Cornell University, Ithaca, NY, USA; ${ }^{7}$ Department of Pediatrics, Washington University School of Medicine, St Louis, MO, USA; ${ }^{8}$ University of Malawi, Blantyre, Malawi; ${ }^{9}$ Division of Biological Anthropology, Department of Archaeology and Anthropology, University of Cambridge, UK; ${ }^{10}$ Escola Paulista de Medicina, Universidade Federal de São Paulo, São Paulo, Brasil; ${ }^{11}$ School of Population and Public Health, University of British Columbia, Vancouver, BC, Canada V6T 1Z3
\end{abstract}

\begin{abstract}
Objectives To determine whether antibiotic treatment leads to improvements in growth in prepubertal children in low and middle income countries, to determine the magnitude of improvements in growth, and to identify moderators of this treatment effect.

Design Systematic review and meta-analysis.

Data sources Medline, Embase, Scopus, the Cochrane central register of controlled trials, and Web of Science.

Study selection Randomised controlled trials conducted in low or middle income countries in which an orally administered antibacterial agent was allocated by randomisation or minimisation and growth was measured as an outcome. Participants aged 1 month to 12 years were included. Control was placebo or non-antimicrobial intervention.

Results Data were pooled from 10 randomised controlled trials representing 4316 children, across a variety of antibiotics, indications for treatment, treatment regimens, and countries. In random effects models, antibiotic use increased height by $0.04 \mathrm{~cm} / \mathrm{month}(95 \%$ confidence interval 0.00 to 0.07$)$ and weight by $23.8 \mathrm{~g} / \mathrm{month}(95 \%$
\end{abstract}

confidence interval 4.3 to 43.3). After adjusting for age, effects on height were larger in younger populations and effects on weight were larger in African studies compared with other regions.

Conclusion Antibiotics have a growth promoting effect in prepubertal children in low and middle income countries. This effect was more pronounced for ponderal than for linear growth. The antibiotic growth promoting effect may be mediated by treatment of clinical or subclinical infections or possibly by modulation of the intestinal microbiota. Better definition of the mechanisms underlying this effect will be important to inform optimal and safe approaches to achieving healthy growth in vulnerable populations.

\section{Introduction}

Undernutrition in early childhood, characterised by poor linear or ponderal growth, underlies approximately one third of all mortality in children aged under 5 years worldwide. ${ }^{1}$ Linear growth, measured as height or length, is an indicator of long term nutritional status; children whose height for age is more than 2 standard deviations below the reference population mean 
are termed stunted. Ponderal growth, measured as body weight, is viewed as an indicator of short term or long term nutritional status. Children whose weight for age is more than 2 standard deviations below the reference population mean are termed underweight. Underweight and stunting, particularly during the first two years of life, have short term effects on morbidity and mortality and long term effects on cognition, educational achievement, and economic productivity as an adult. ${ }^{2}$ Given the current global focus on reducing underweight and stunting to reach forthcoming global health targets, ${ }^{3}{ }^{4}$ interest in evaluating interventions to promote healthy growth in childhood is increasing. ${ }^{5}$ Primary interventions to improve growth in children have largely focused on nutritional supplementation and prevention of diarrhoea. However, the impact of these interventions on restoring growth deficits in undernourished children is modest. ${ }^{6-9}$ Restoration of deficits in linear growth is particularly challenging beyond the first two years of life. ${ }^{2}$

The growth promoting effects of antibiotics were first observed in animals in the 1940s. Small daily doses of broad spectrum antibiotics have been found to improve average daily weight gain in farm animals by as much as $73 \% .{ }^{10-18}$ These observations led to the hypothesis that food animals reared in conditions of poor sanitation and hygiene have impaired growth because of chronic exposure to environmental microbes and pathogens, and that antibiotic treatment may therefore improve growth. ${ }^{19}$

In humans, an association between infections and malnutrition in children is supported in the literature. ${ }^{2021}$ Nutrient harvesting from the diet and the inflammatory response of the gut are also modulated by the intestinal microbiota, a microbial ecosystem that is essential to human health and nutrition. ${ }^{22-26}$ Perturbation of this microbial community through chronic exposure to environmental microbes or pathogens may also be detrimental to growth in children, ${ }^{19}{ }^{27-29}$ and studies have shown that antibiotic use can affect the composition of the microbial community. ${ }^{30}{ }^{31}$ Antibiotic use has also been associated with significant height and weight gains among children in some target populations. ${ }^{32-35}$ However, results have not always been consistent, ${ }^{32}{ }^{36-39}$ and researchers continue to investigate the potential co-benefits of antibiotic treatment on growth in children. $^{4041}$

We carried out a systematic review of randomised controlled trials to determine whether improvements in growth are seen among prepubertal children ( 1 month to 12 years old) treated with antibiotics in low and middle income countries; to determine the magnitude of these growth effects; and to identify moderators of this treatment effect. We hypothesised that antibiotics would have a positive average effect on both height and weight, and that treatment effect size would be moderated by the characteristics of antibiotic treatment, differences in study population, and trial quality.

\section{Methods}

\section{Search strategy and selection criteria}

This review is reported in accordance with the PRISMA statement ${ }^{42}$ and recommendations for reporting meta-analyses of individual patient data. ${ }^{43}$ We searched Medline (including In-Process and Other Non-Indexed Citations) and Embase, both using Ovid, as well as Scopus and the Cochrane central register of controlled trials up to 12 December 2013. A professional librarian helped to develop the search strings (see supplementary appendix 1 for details of search strings and appendix 2 for the review protocol).
We searched for randomised controlled trials conducted in low or middle income countries with participants aged 1 month to 12 years allocated by randomisation or minimisation to antibacterial treatment given by mouth, or to control. Control interventions included placebo, an intervention with no known antimicrobial effect, or no treatment. We selected trials, published or unpublished, if growth was measured as an outcome. Studies of anthelmintic treatments were excluded, since systematic reviews of such trials have already been conducted. ${ }^{44}$ We placed no restrictions on language, year of publication, or the length of follow-up, and excluded quasiexperimental studies, observational studies, reviews, and simulations. We excluded studies of neonates ( $<1$ month old) since growth patterns during the neonatal period, particularly among preterm infants, are different from the post-neonatal period. Finally, we considered trials ineligible for inclusion if the condition being treated did not depend on the antimicrobial effect of antibiotic treatment (for example, use of specific antibiotics to reduce feeding intolerance through prokinetic effects or to improve lung function through anti-inflammatory effects).

Two investigators (EKG and SMAJ) independently assessed titles and abstracts for eligible publications. If eligibility could not be determined, the full article was retrieved and the methods screened. In an effort to find similar trials we used Web of Science to search for publications that cited the included studies, and we also handsearched reference lists of included trials and any review articles identified. A third investigator (AJP) adjudicated discrepancies.

\section{Data abstraction and analysis}

Study quality was determined by assessing the included publications for risk of bias from the procedures used for sequence generation, allocation concealment, and blinding; and by informative censoring or selective outcome reporting using a standardised instrument adapted from the Cochrane handbook. ${ }^{46}$ Two reviewers (EKG and SMAJ) independently assessed the included publications. Discrepancies were resolved by consensus.

We contacted study authors up to three times by email (or by telephone if email was unsuccessful) to determine their interest in collaborating on this review and to request individual patient data. When such data could not be obtained, the same two reviewers independently abstracted data using a standardised pretested form, with discrepancies resolved by consensus. For each trial arm we abstracted number of participants, number lost to follow-up or excluded after randomisation, mean baseline height or weight, and mean height or weight (and standard deviations) at the end of follow-up. For reported treatment effects we also abstracted $P$ values, confidence intervals, and standard errors. Where mean change in height or weight for each unit of follow-up time was reported, we retrieved the same information. We also abstracted several trial level characteristics, which we defined a priori as potential moderators of treatment effect: indication for treatment, country, proportion boys, mean age, antibiotic agent, dosage, frequency and duration of antibiotic treatment, concurrent interventions, length of follow-up, and whether treatment effects were adjusted for imbalances at baseline. We defined antibiotic class as bacteriostatic or bactericidal, and antibiotic spectrum as broad or narrow. Broad spectrum antibiotics were defined as those reported in the literature to be effective against a wide range of Gram positive and Gram negative bacteria, and narrow spectrum antibiotics as those reported in the literature to be effective 
against a limited range of bacteria. ${ }^{47-55}$ Risk of bias domains were treated as potential sources of heterogeneity.

Outcomes were mean height $(\mathrm{cm})$ or weight $(\mathrm{g})$ at the end of follow-up or mean change in height $(\mathrm{cm})$ or weight $(\mathrm{g})$ per unit of follow-up time. The difference in means between treatment and control arms was the measure of treatment effect. We scaled the treatment effects and their variances as the average effect for each month of follow-up. We analysed height and weight separately. When a trial allocated participants to more than one intervention, we abstracted data from the arm allocated to receive antibiotics. ${ }^{56-58}$ When a trial allocated participants to more than one antibiotic arm, we combined the data from both arms to avoid unit of analysis errors. ${ }^{3459}$

We combined individual patient data and aggregate data using a two step approach. ${ }^{60}$ In the first step we estimated treatment effects in each trial with individual patient data in an intention to treat analysis using linear mixed models to allow for random intercepts and serial correlation. For each trial we fit one individual patient data model, with baseline growth, age, sex, duration of follow-up, and a duration by treatment interaction included as covariates. In the second step we used a random effects model to pool intention to treat effect estimates (obtained from separate individual patient data trials in step 1) with intention to treat effect estimates abstracted from publications with aggregate data.

We assessed statistical heterogeneity using the $\mathrm{I}^{2}$ statistic. ${ }^{61}$ Heterogeneity was explored using weighted metaregression and subgroup meta-analyses. Statistical significance was evaluated at $\alpha<0.05$. We assessed publication bias using Egger's test. ${ }^{61}$ Sensitivity analyses were performed in two ways: to determine the robustness of meta-analysis results to the removal of studies, ${ }^{62}$ and by fitting linear mixed models restricted to the five trials for which individual patient data were available.

Trials with individual patient data were modelled using the lme4 package, and we fit all meta-analyses and metaregression models using the metafor package, ${ }^{63}$ both using R version 2.15.1.

\section{Results}

\section{Study selection}

The electronic search identified 4600 records. An additional 24 records were identified through Web of Science and a backward search of reference lists (fig $1 \Downarrow$ ). Of these, 190 studies were retrieved and screened for eligibility. Overall, 139 studies failed to meet at least two selection criteria. Thirty four additional studies were excluded for failing to meet one of the following criteria: no antibiotic was allocated $(n=8)$, an active comparator was used $(n=7)$, the trial was not conducted in a low or middle income country $(n=5)$, treatment was not randomised $(n=5)$, growth was not measured or reported $(n=4)$, participants' age range exceeded 12 years $(n=2)$, review articles $(n=2)$, and the antibiotic was not administered orally $(n=1)$. Only four were non-English language texts. These were screened using an electronic translator.

Four additional trials were excluded because they reported differences in prevalence of stunting or wasting, ${ }^{64-66}$ or reported growth using the Wetzel grid method. ${ }^{67}$ Of these, three authors could not be reached to request individual patient data or unpublished data, ${ }^{64667}$ and data were no longer available from one. ${ }^{65}$ Another author was contacted and provided individual patient data but did not provide a data dictionary. Since this publication did not report outcomes for the antibiotic arms, this trial was excluded. ${ }^{68}$ Of these five otherwise eligible randomised controlled trials that were excluded because growth was not reported in the desired format, four reported no growth benefits from antibiotics, ${ }^{64-6668}$ but they would only have represented $8 \%$ of the total person time if they were included and would not have greatly influenced our findings. Another two trials were excluded because they only reported growth at baseline and the authors could not be reached. ${ }^{69} 70$

Published data were available from five trials, ${ }^{5658} 597172$ and complete datasets for individual patient data were obtained from five trials. ${ }^{33-35} 5773$ Thus 10 randomised controlled trials were included in the meta-analysis. ${ }^{33-35} 56-59$ 71-73 Only data from the secnidazole and placebo arms were included for Goto and colleagues, ${ }^{57}$ from the metronidazole and placebo arms for Gupta and colleagues, ${ }^{58}$ and from the metronidazole and no intervention arms for Heikens and colleagues. ${ }^{56}$

\section{Study characteristics}

Of these 10 trials, nine were placebo controlled and one gave the controls no treatment. ${ }^{56}$ Indication for treatment varied by trial and included malnutrition $(\mathrm{n}=4)$, infection with Giardia lamblia $(\mathrm{n}=2)$, diarrhoea with or without vomiting $(\mathrm{n}=2)$, environmental enteropathy $(\mathrm{n}=1)$, and prophylaxis in children infected with human immunodeficiency virus $(n=1)$. The earliest included trial was published in 1953 and the most recent in 2013. Three trials gave a nutritional supplement to participants in both arms $s^{34571}$ in addition to antibiotics or control (table $1 \Downarrow$ ). Only three trials with aggregate data reported the number of male participants (table $2 \Downarrow$ ). Two trials recruited children admitted to hospital, and both reported weight only. ${ }^{33} 72$ Eight trials reported height ${ }^{3435} 56-597173$ and all reported weight. ${ }^{33-35}{ }^{56-59} 7^{71-73}$ Four trials with individual patient data reported height ${ }^{34} 355773$ and five reported weight. ${ }^{33-35} 5773$ Together these trials included 1699 control and 2617 antibiotic treated participants, followed-up for a mean of 268 (SD 266) days, across seven countries. The mean age of participants ranged from 4 to 115 months (table 2). On average, trial participants were below the age standardised reference population mean for height or weight at baseline (table 1).

\section{Risk of bias}

Only one trial ${ }^{59}$ was evaluated to be at high risk for bias overall (that is, when all bias domains were considered together). This was based on high risk as a result of inadequate random sequence generation, since treatment was randomly allocated to groups of children determined by the investigators; unclear risk due to inadequate allocation concealment; and high risk from differential attrition between treatment arms. Five trials were ranked as low risk for bias overall. These trials were low risk in all six bias domains..$^{33-35} 577^{73}$ Finally, four trials had an unclear risk for bias overall because the procedures were not fully described. ${ }^{56587172}$

For risk of bias due to attrition, the linear mixed models fit for the five trials with individual patient data were unbiased by losses to follow-up, provided the losses were uninformative conditional on observed height and weight. Among the trials with aggregate data only Guzman and colleagues ${ }^{59}$ was determined as being impacted by drop outs. Gupta and colleagues $^{58}$ reported exclusions before randomisation but reported outcomes on all 79 participants recruited at baseline. Heikens and colleagues ${ }^{56}$ reported that drop outs predominantly consisted of participants who moved too far from the study site to be followed-up or withdrew consent ( $9 \%$ and $2 \%$ of the total sample, respectively). Risk of bias due to attrition could not be assessed in the two remaining trials with aggregate data because the authors did not provide any data on exclusion of participants 
during the study. ${ }^{71}$ However, these trials only accounted for $5.9 \%{ }^{71}$ of the weights in the pooled treatment effect for height, and $1.2 \%$ and $1.4 \%{ }^{72}$ in the pooled treatment effect for weight. Overall, we do not think that attrition posed a serious risk of bias in our analyses.

Egger's test suggested no significant publication bias among trials reporting height $(\mathrm{P}=0.841)$ or weight $(\mathrm{P}=0.391)$.

\section{Meta-analysis}

Our random effects models estimated an average treatment effect for height of $0.04 \mathrm{~cm} /$ month $(95 \%$ confidence interval 0.00 to 0.07 , fig $2 \Downarrow)$, and an average effect for weight of 23.8 $\mathrm{g} / \mathrm{month}$ (95\% confidence interval 4.3 to 43.3 ) in antibiotic treated compared with control children (fig $3 \Downarrow$ ). The $\mathrm{I}^{2}$ statistic showed a considerable degree of statistical heterogeneity in treatment effects for both height and weight $(84.8 \%$ and $84.4 \%$, respectively).

To assess the impact of antibiotic treatment on growth in children aged less than 2 years, we used the same two step approach described for the analysis using complete data. We fitted models of individual patient data restricted to participants less than 2 years old ${ }^{33-35} 57$ and pooled these treatment effect estimates with the estimates for aggregated data reported by Heikens and colleagues, ${ }^{56}$ which was the only trial with aggregated data restricted to this age group. These included observations from 833 control and 1461 treated infants, followed up for a mean 169 (SD 152) days. The treatment effect in these children was not statistically significant for height $(0.03$ $\mathrm{cm} /$ month, $95 \%$ confidence interval -0.05 to 0.11 ) but was for weight ( $29.6 \mathrm{~g} /$ month, $95 \%$ confidence interval 2.4 to 56.8$)$, $\mathrm{I}^{2}=47.0 \%$.

\section{Metaregression analyses}

Only geographical region significantly explained variation in the treatment effect across trials for weight (table $3 \Downarrow$ ). The treatment effect was $35.6 \mathrm{~g} / \mathrm{month}$ larger on average in trials conducted in Africa (95\% confidence interval 12.8 to 58.3) compared with trials conducted in other regions. No statistically significant moderators of the height treatment effect were identified by bivariate analyses. We could not investigate risk of bias domains as moderators of treatment effect because only one trial was evaluated as high risk in any domain. All bivariate models included one treatment effect moderator and one outcome (table 3).

Duration of treatment, geographical region, treatment for Giardia lamblia infection, and age were statistically significant moderators of treatment effect, after adjustment for mean age of study population (table $4 \Downarrow$ ). The height treatment effect was $0.001 \mathrm{~cm} /$ month ( $95 \%$ confidence interval -0.002 to 0.000 ) smaller on average with each one month increase in mean population age, and was $0.007 \mathrm{~cm} / \mathrm{month}$ larger on average with each additional day of treatment ( 0.00 to 0.01$)$. The weight treatment effect was $0.5 \mathrm{~g} /$ month smaller on average $(95 \%$ confidence interval -1.0 to -0.1 ) with each one month increase in mean age, $33.2 \mathrm{~g} /$ month (5.3 to 61.2) larger on average in trials conducted in Africa, and $46.9 \mathrm{~g} /$ month ( -83.2 to -10.6$)$ smaller on average in trials in which participants were treated for $G$ lamblia infection. In this last model, the intercept was $62.1 \mathrm{~g} /$ month (95\% confidence interval 29.3 to 94.9 ), indicating a significant treatment effect in trials that did not treat children for G lamblia infection. All mean age adjusted models included mean participants' age, one treatment effect moderator, and one outcome (table 4).

\section{Sensitivity analyses}

Only removal of Prendergast and colleagues ${ }^{35}$ from the random effects model impacted the average effect for height. Without this trial the average effect was $0.02 \mathrm{~cm} /$ month $(95 \%$ confidence interval -0.01 to 0.05$)$, a $50 \%$ decrease. The average treatment effect for weight was robust to the removal of trials. Also, two trials recruited children admitted to hospital. ${ }^{33} 72$ Simultaneous exclusion of both trials did not change the average treatment effect for weight $(21.5 \mathrm{~g} /$ month, $95 \%$ confidence interval 2.3 to 40.7). These two trials did not report height.

In addition we fit linear mixed models to investigate whether adjusting for participant age at the individual level (using trials with individual patient data only) would produce the same estimates of treatment effect moderation as we obtained by weighted metaregression adjusted for mean participant age (table 4). These models included age and duration of treatment, geographical region, or treatment for $G$ lamblia infection, along with corresponding interaction terms. Results of these individual patient data models were consistent with the weighted metaregression results using all trials, with the exception of age, where the treatment effect on weight increased by $0.8 \mathrm{~g} / \mathrm{month}$ for each one month increase in child age on average.

\section{Subgroup analyses}

The weight treatment effect was homogeneous across trials conducted in Africa using a random effects model (41.4 $\mathrm{g} /$ month, $95 \%$ confidence interval 31.0 to 51.7$) ; \mathrm{I}^{2}=0.0 \%$. The average treatment effect estimated in this subgroup was identical when a fixed effects model was used $(41.4 \mathrm{~g} /$ month, 31.0 to 51.7).

\section{Discussion}

In this pooled analysis of individual patient data and aggregate data from 10 randomised controlled trials conducted in seven low and middle income countries, antibiotic treatment had a positive average treatment effect on both height and weight in children aged 1 month to 12 years. Our results suggest that the growth promoting effect of antibiotics is more substantial for ponderal growth than for linear growth, and that the effect may be more homogenous in younger children. Analysis from the trials with individual patient data showed an increase in the weight treatment effect with increasing participants' age. This is in contrast with the results of the metaregression model, which suggested a smaller effect with increasing mean age. The trials with individual patient data primarily included children less than 5 years old, whereas two trials with aggregate data recruited older children. ${ }^{51}{ }^{79}$ Cross level bias may also partly explain this discrepancy. Although we did not restrict study selection to populations with a particular nutritional status, children were generally below the age standardised reference population mean for height or weight, reflecting the spectrum of stunting and wasting malnutrition seen in low and middle income countries. The larger weight treatment effects we observed in trials conducted in Africa may plausibly be explained by the high prevalence of HIV infection and severe acute malnutrition among populations included in these studies. Two trials conducted in Africa included severely malnourished children in whom all or a subset were infected with or exposed to HIV ${ }^{34}{ }^{35}$ A third trial also included children from a similar high HIV prevalence community, ${ }^{34} 73$ although HIV status was not specifically reported. The smaller weight treatment effect we observed in trials treating children for G lamblia infection suggested that growth may not be as strongly impacted in children treated with antibiotics for this specific protozoal 
infection. Overall, the average treatment effects we observed would correspond to an approximate 0.1 increase in height for age $\mathrm{Z}$ score and a 0.2 to 0.3 increase in weight for age $\mathrm{Z}$ score over six months in HIV infected, HIV exposed, or severely malnourished populations under 2 years old using the World Health Organization growth standard. ${ }^{74}$ These treatment effects therefore represent clinically relevant growth gains for the youngest children from the most vulnerable populations, in whom the long term impact of undernutrition is most profound.

\section{Strengths and limitations of this study}

The inclusion of trials with individual patient data and aggregate data served to improve the precision of our pooled estimates, minimised the risk of publication bias, ${ }^{60}$ and allowed us to define height and weight in uniform units, avoiding the potential sources of bias inherent in utilising standardised mean differences. ${ }^{75}$ We synthesised data from 4316 children, observed across a variety of antibiotics, indications for treatment, treatment regimens, and countries, providing the first comprehensive review of evidence from all randomised trials relating antibiotic use to growth in children in low and middle income countries, conducted over a 60 year period. A clear limitation of pooling such a diverse set of trials, with a large degree of statistical heterogeneity, is the limited generalisability of the average treatment effects. It is not completely clear which antibiotics or treatment regimens can be expected to produce these growth effects in other populations. However, pooling this diverse set of trials did allow identification of important subpopulations in whom the growth effect may be more profound when broad spectrum antibiotics are used. However, owing to the small number of trials, we had limited power to identify moderators of treatment effect, and we were not able to fully investigate trial level confounding with multivariable metaregression models. Specifically, the potential modifying effect of HIV prevalence, treatment duration, antibiotic class, concurrent nutritional interventions, and study population characteristics could not be fully elucidated. Also, cross level bias cannot be ruled out in our metaregression analyses of treatment effect moderators (which are measured at trial level); hence care must be taken in extending the treatment modifying effects to the individual level, particularly for age. Egger's test showed no evidence of publication bias. Careful screening of search results and communication with investigators ensured identification of published and unpublished reports. Finally, only one trial was evaluated to be at high risk for bias. ${ }^{59}$

\section{Comparison with other studies}

The exact reasons for the observed growth effects from antibiotics remain unclear, but several mechanisms may be involved. Respiratory and gastrointestinal infections are known to be associated with undernutrition. Malabsorption of nutrients, increased nutrient loss during episodes of diarrhoea, gut inflammation, impaired intestinal barrier function, diversion of nutrients away from growth to support immune activation, and loss of appetite are possible reasons for impaired growth during infection. ${ }^{19-21}$ Antibiotics may improve growth by resolving subclinical and clinical infections. Eradication of microbes that regulate endocrine hunger signals may also contribute to growth gains with antibiotics. Changes in post-meal leptin and ghrelin serum levels, both of which help to regulate satiety, have been associated with the eradication of Helicobacter pylori following antibiotic treatment, ${ }^{76}$ although this may play less of a role in food insecure settings.

An alternative possibility is that alteration of the intestinal microbiota by antibiotics may result in growth gains. ${ }^{77-79}$ The intestinal microbiota regulates immune development and inflammation in the gut, ${ }^{23}$ maintains host-microbe homeostasis in the gut, ${ }^{25}$ and has an important role in nutrient harvesting and absorption..$^{26}$ Disturbance of intestinal microbiota composition resulting from chronic intestinal colonisation with pathogens or overgrowth of commensal bacteria in the small intestine ${ }^{19} 27-29$ may lead to disruption of these functions. Perturbation of the intestinal microbiota may also lead to intestinal inflammation and increased intestinal permeability. These changes are characteristic of environmental enteropathy, a subclinical disorder of the intestinal tract that is ubiquitous in developing countries and is associated with poor linear growth. ${ }^{19}{ }^{27-29}$

Antibiotics are known to induce changes in the composition of microbiota in the gut, ${ }^{30} 31$ and these changes may persist. ${ }^{77} 79$ Recent work has shown that intestinal microbial taxa may not return to their pretreatment abundance levels, even after a single use of antibiotics ${ }^{77}{ }^{79}$; ; however, the extent of recovery to baseline may depend on the class of antibiotic used. ${ }^{79} \mathrm{~A}$ recent review qualitatively summarised the evidence supporting a relation between antibiotic use and weight and included evidence from some trials in humans. ${ }^{77}$ The mechanisms underlying these growth benefits plausibly include resolution of underlying infections or inflammatory processes (for example, environmental enteropathy) or alteration of intestinal microbiota composition and function. In an experimental animal model, weight loss in mice resulted from transplantation of donor faeces from children with kwashiorkor, but not from their healthy twins, ${ }^{81}$ whereas increases in total body mass and fat mass were induced in mice transplanted with donor faeces from obese adults, but not from their lean twins. ${ }^{82}$ Although we cannot rule out an effect of antibiotics on latent bacterial infections in the included trials, it is plausible that the growth benefits we observed also encompass an important growth effect mediated by intestinal microbiota.

\section{Conclusions and policy implications}

In summary, our results show that antibiotic treatment has a growth promoting effect, particularly for ponderal growth, in prepubertal children from undernourished populations in low and middle income countries. Linear growth seems less responsive to antibiotics. A better understanding of the biological mechanisms behind these antibiotic associated effects on growth is critical for certain populations, such as children under 2 years old (as reversal of stunting beyond this age is challenging ${ }^{2}$ ), and HIV infected, HIV exposed, and acutely malnourished children in whom antibiotics continue to be a standard component of care. ${ }^{368384}$ Antibiotics, however, are not the most viable option for the treatment of malnutrition outside of these highly vulnerable populations in which antibiotic treatment is already routinely recommended for treatment and prevention of infections. In addition to concerns about antimicrobial resistance, antibiotic use has also been associated with adverse events such as antibiotic associated diarrhoea. The growth benefits of more widespread antibiotic use may not outweigh the risks. Our findings highlight the co-benefits of antimicrobial treatment that have been previously reported from developing countries ${ }^{34} 35$ and provide an intriguing proof of concept that treatment of subclinical infections and modulation of the intestinal microbiota may have beneficial effects on growth.

We thank Genevieve Gore, librarian at the McGill University Life Sciences Library, for her expert assistance with the electronic literature search. 


\section{What is already known on this topic}

Antibiotics have shown variable effects on growth in humans but are currently recommended for severely malnourished children and those infected with or exposed to HIV to reduce morbidity and mortality

Several mechanisms exist through which antibiotic treatment may affect growth in children, including resolution of infection and, potentially, alteration of the intestinal microbiota

\section{What this study adds}

Evidence from a diverse set of randomised controlled trials show that antibiotic use in prepubertal children from undernourished populations in low and middle income countries leads to clinically relevant growth gains, particularly for weight

Larger growth gains are associated with antibiotic use in studies with a high prevalence of HIV infection and severe acute malnutrition The growth gains show the co-benefits of antibiotic treatment in high risk populations, and provide proof of concept that treatment of infections or modulation of the intestinal microbiota can have beneficial growth effects; however, more research is needed to better understand the mechanisms involved

Contributors: EKG, EEEM, JHH, RJS, and ARM created and designed the study. EKG and SMAJ conducted the literature search, study selection, and data collection. AJP adjudicated study selection. AJP, DMG, ASW, IT, RG, ST, and MBdM provided individual patient data, and provided insight into trial design, implementation, and database structure. EKG did the data analysis. EKG, EEEM, and ARM interpreted the data and drafted the manuscript. All authors critically revised the manuscript for intellectual content, discussion of findings, and overall conclusions. ARM is the guarantor.

Funding: EKG was supported by the Vanier Canada Graduate Scholarship. The funders had no role in the study design, data collection and analysis, decision to publish, or preparation of the manuscript.

Competing interests: All authors have completed the ICMJE uniform disclosure form at www.icmje.org/coi_disclosure.pdf and declare: no support from any organisation for the submitted work; no financial relationships with any organisations that might have an interest in the submitted work in the previous three years; no other relationships or activities that could appear to have influenced the submitted work.

\section{Ethical approval: Not required.}

Transparency: ARM affirms that this manuscript is an honest, accurate, and transparent account of the study being reported; that no important aspects of the study have been omitted; and that any discrepancies from the study as planned have been explained.

Data sharing: The electronic data abstraction form is available from the first author at ethan.gough@mail.mcgill.ca.

1 Black RE, Victora CG, Walker SP, Bhutta ZA, Christian P, de Onis M, et al. Maternal and child undernutrition and overweight in low-income and middle-income countries. Lancet 2013;382:427-51

2 Victora CG, Adair L, Fall C, Hallal PC, Martorell R, Richter L, et al. Maternal and child undernutrition: consequences for adult health and human capital. Lancet 2008;371:340-57.

3 United Nations. The millennium development goals report: 2013. http://mdgs.un.org/unsd/ $\mathrm{mdg} /$ Resources/Static/Products/Progress2013/English2013.pdf.

4 De Onis M, Dewey KG, Borghi E, Onyango AW, Blössner M, Daelmans B, et al. The World Health Organization's global target for reducing childhood stunting by 2025: rationale and proposed actions. Matern Child Nutr 2013;9:6-26.

5 Bhutta ZA, Das JK, Rizvi A, Gaffey MF, Walker N, Horton S, et al. Evidence-based interventions for improvement of maternal and child nutrition: what can be done and at what cost? Lancet 2013;382:452-77.

6 Bhutta ZA, Ahmed T, Black RE, Cousens S, Dewey K, Giugliani E, et al. What works? Interventions for maternal and child undernutrition and survival. Lancet2008:371:417-40.

7 Checkley W, Buckley G, Gilman RH, Assis AM, Guerrant RL, Morris SS, et al. Multi-country analysis of the effects of diarrhoea on childhood stunting. Int J Epidemiol 2008;37:816-30.

8 Briend A, Hasan KZ, Aziz KMA, Hoque BA. Are diarrhoea control programmes likely to reduce childhood malnutrition? Observations from rural bangladesh. Lancet 1989;2:319-22.

9 Black RE. Would control of childhood infectious diseases reduce malnutrition? Acta Paediatr Scand 1996:374:133-40.

10 Hirschhorn N. Can small daily doses of antibiotics prevent the cycle of diarrhea, malabsorption, and malnutrition in children? Am J Clin Nutr 1971;24:872-5.

11 Kantas D, Vassilopoulos V, Kyriakis SC, Saoulidis K. A dose titration study on the effect of virginiamycin on gilt/sow and piglet performance. Zentralb/ Veterinarmed $A$ 1998;45:525-33.

12 Giannakopoulos CG, Kyriakis SC, Saoulidis K, Spais A, Vassilopoulos V, Alexopoulos C. The effect of salinomycin on health status and performance of sows and their litters: a dose titration study. J Vet Med A Physiol Pathol Clin Med 2001;48:257-65.

13 Weber TE, Schinckel AP, Houseknecht KL, Richert BT. Evaluation of conjugated linoleic acid and dietary antibiotics as growth promotants in weanling pigs. $J$ Anim Sci 2001;79:2542-9.

14 Dritz SS, Tokach MD, Goodband RD, Nelssen JL. Effects of administration of antimicrobials in feed on growth rate and feed efficiency of pigs in multisite production systems. J Am Vet Med Assoc 2002;220:1690-5.
15 Parks CW, Grimes JL, Ferket PR. Effects of virginiamycin and a mannanoligosaccharide-virginiamycin shuttle program on the growth and performance of large white female turkeys. Poult Sci 2005;84:1967-73.

16 Packer EL, Clayton EH, Cusack PM. Rumen fermentation and liveweight gain in beef cattle treated with monensin and grazing lush forage. Aust Vet $J$ 2011;89:338-45.

17 Rérat M, Albini S, Jaquier V, Hüssy D. Bovine respiratory disease: efficacy of different prophylactic treatments in veal calves and antimicrobial resistance of isolated pasteurellaceae. Prev Vet Med 2012;103:265-73.

18 Bosi P, Merialdi G, Scandurra S, Messori S, Bardasi L, Nisi I, et al. Feed supplemented with 3 different antibiotics improved food intake and decreased the activation of the humoral immune response in healthy weaned pigs but had differing effects on intestinal microbiota. J Anim Sci 2011;89:4043-53.

19 Dewey KG, Mayers DR. Early child growth: how do nutrition and infection interact? Matern Child Nutr 2011;7:129-42.

20 Guerrant RL, Oriá RB, Moore SR, Oriá MO, Lima AA. Malnutrition as an enteric infectious disease with long-term effects on child development. Nutr Rev 2008;66:487-505.

21 Rodríguez L, Cervantes E, Ortiz R. Malnutrition and gastrointestinal and respiratory infections in children: a public health problem. Int $J$ Environ Res Public Health 2011;8:1174-205.

22 Palmer C, Bik EM, DiGiulio DB, Relman DA, Brown PO. Development of the human infant intestinal microbiota. PLoS Biol 2007:5:e177.

23 Maynard CL, Elson CO, Hatton RD, Weaver CT. Reciprocal interactions of the intestinal microbiota and immune system. Nature 2012:489:231-41.

24 Hooper LV. Do symbiotic bacteria subvert host immunity? Nat Rev Microbiol 2009;7:367-74.

25 Chung H, Kasper DL. Microbiota-stimulated immune mechanisms to maintain gut homeostasis. Curr Opin Immunol 2010;22:455-60.

26 Tremaroli V, Bäckhed F. Functional interactions between the gut microbiota and host metabolism. Nature 2012;489:242-9.

27 Humphrey JH. Child undernutrition, tropical enteropathy, toilets, and handwashing. Lancet 2009;374:1032-5.

28 Lunn PG. The impact of infection and nutrition on gut function and growth in childhood. Proc Nutr Soc 2000;59:147-54.

29 Prendergast A, Kelly P. Enteropathies in the developing world: neglected effects on global health. Am J Trop Med Hyg 2012;86:756-63.

30 Sullivan A, Edlund C, Nord CE. Effect of antimicrobial agents on the ecological balance of human microflora. Lancet Infect Dis 2001;1:101-14.

31 Rafii F, Sutherland JB, Cerniglia CE. Effects of treatment with antimicrobial agents on the human colonic microflora. Ther Clin Risk Manag 2008;4:1343-58

32 Rosenberg IH, Beisel WR, Gordon JE, Katz M, Keusch GT, Luckey TD, et al. Infant and child enteritis-malabsorption-malnutrition: the potential of limited studies with low-dose antibiotic feeding. Am J Clin Nutr 1974;27:304-9.

33 Tahan S, Morais MB, Wehba J, Scaletsky IC, Machado AM, Silva LQ, et al. A randomized double-blind clinical trial of the effect of non-absorbable oral polymyxin on infants with severe infectious diarrhea. Braz J Med Biol Res 2007;40:209-19.

34 Trehan I, Goldbach HS, LaGrone LN, Meuli GJ, Wang RJ, Maleta KM, et al. Antibiotics as part of the management of severe acute malnutrition. N Engl J Med 2013;368:425-35.

35 Prendergast A, Walker AS, Mulenga V, Chintu C, Gibb DM. Improved growth and anemia in HIV-infected African children taking cotrimoxazole prophylaxis. Clin Infect Dis 2011;52:953-6.

36 Lazzerini M, Tickell D. Antibiotics in severely malnourished children: systematic review of efficacy, safety and pharmacokinetics. Bull World Health Organ 2011;89:594-607.

37 Dutta S, Chowdhary G, Kumar P, Mukhopadhay K, Narang A. Ciprofloxacin administration to very low birth weight babies has no effect on linear growth in infancy. $J$ Trop Pediatr 2006;52:103-6.

38 Trehan I, Amthor RE, Maleta K, Manary MJ. Evaluation of the routine use of amoxicillin as part of the home-based treatment of severe acute malnutrition. Trop Med Int Health 2010;15:1022-8.

39 Ahmed AS, Khan NZ, Saha SK, Chowdhury MA, Muslima H, Law P, et al. Ciprofloxacin treatment in preterm neonates in Bangladesh: lack of effects on growth and development. Pediatr Infect Dis J 2006:25:1137-41.

40 Amza A, Kadri B, Nassirou B, Stoller NE, Yu SN, Zhou Z, et al. A cluster-randomized controlled trial evaluating the effects of mass azithromycin treatment on growth and nutrition in Niger. Am J Trop Med Hyg 2013;88:138-43.

41 Isanaka S. The effect of routine antibiotic use in the outpatient treatment of severely malnourished children without complications: Maradi, Niger. 2013. http://clinicaltrials.gov/ ct2/show/record/NCT01613547.

42 Liberati A, Altman DG, Tetzlaff J, Mulrow C, Gøtzsche PC, loannidis JP, et al. The PRISMA statement for reporting of systematic reviews and meta-analyses of studies that evaluate health care interventions: explanation and elaboration. PLoS Med 2009;6:e1000100

43 Riley RD, Lambert PC, Abo-Zaid G. Meta-analysis of individual participant data: rationale, conduct and reporting. BMJ 2010;340:c221.

44 Taylor-Robinson DC, Jones AP, Garner P. Deworming drugs for treating soil-transmitted intestinal worms in children: effects on growth and school performance. Cochrane Database Syst Rev 2007;4:CD000371. 
45 Dickson R, Awasthi S, Williamson P, Demellweek C, Garner P. Effects of treatment for intestinal helminth infection on growth and cognitive performance in children: systematic review of randomised trials. BMJ 2000;320:1697-1701.

46 Higgins JPT, Altman DG, Sterne JAC. Chapter 8: assessing risk of bias in included studies. In: Higgins JPT, Green S, eds. Cochrane handbook for systematic reviews of interventions, version 5.1.0 (updated March 2011). Cochrane Collaboration, 2011. 2012. www.cochranehandbook.org.

47 Crofton J. Aureomycin. Postgrad Med J 1950;26:368-71

48 Garrod LP. Relative antibacterial activity of three penicillins. BMJ 1960;1:527-9.

49 Smith CL, Powell KR. Review of the sulfonamides and trimethoprim. Pediatr Rev 2000;21:368-71

50 Montovani PAB, Pinto AMP, dos Santos MB, Vieira DI, do Prado AW, Manfio JL. Bioavailability of two oral formulas of secnidazole in healthy volunteers. Braz $J$ Pharm 2009:45:687-92.

51 Tally FP, Goldin BR, Sullivan N, Johnston J, Gorbach SL. Antimicrobial activity of metronidazole in anaerobic bacteria. Antimicrob Agents Chemother 1978;13:460-5.

52 Zavascki AP, Goldani LZ, Li J, Nation RL. Polymyxin B for the treatment of multidrug-resistant pathogens: a critical review. J Antimicrob Chemother 2007;60:1206-15.

53 Scarpignato C, Pelosini I. Rifaximin, a poorly absorbed antibiotic: pharmacology and clinical potential. Chemotherapy 2005:51:36-66.

54 Salvo F, De Sarro A, Caputi AP, Polimeni G. Amoxicillin and amoxicillin plus clavulanate: a safety review. Expert Opin Drug Saf 2009;8:111-8.

55 Guay DR. Cefdinir: an expanded-spectrum oral cephalosporin. Ann Pharmacother 2000;34:1469-77.

56 Heikens GT, Schofield WN, Dawson S. The Kingston project. II. The effects of high energy supplement and metronidazole on malnourished children rehabilitated in the community: anthropometry. Eur J Clin Nutr 1993:47:160-73.

57 Goto R, Mascie-Taylor CG, Lunn PG. Impact of anti-giardia and anthelminthic treatment on infant growth and intestinal permeability in rural Bangladesh: a randomised double-blind controlled study. Trans R Soc Trop Med Hyg 2009;103:520-9.

58 Gupta MC, Urrutia JJ. Effect of periodic antiascaris and antigiardia treatment on nutritional status of preschool children. Am J Clinl Nutr 1982;36:79-86.

59 Guzman MA, Scrimshaw NS, Monroe RJ. Growth and development of Central American children: growth responses of rural Guatemalan school children to daily administration of penicillin and aureomycin. Am J Clin Nutr 1958;6:430-8.

60 Riley RD, Lambert PC, Staessen JA, Wang J, Gueyffier F, Thijs L, et al. Meta-analysis of continuous outcomes combining individual patient data and aggregate data. Stat Med 2008;27:1870-93

61 Deeks JJ, Higgins JPT, Altman DG. Chapter 9: analysing data and undertaking meta-analyses. In: Higgins JPT, Green S, eds. Cochrane handbook for systematic reviews of interventions, version 5.1.0 (updated March 2011). Cochrane Collaboration, 2011. 2012. www.cochrane-handbook.org.

62 Higgins JPT, Deeks JJ, Altman DG. Chapter 16: special topics in statistics. In: Higgins JPT, Green S, eds. Cochrane handbook for systematic reviews of interventions, version 5.1.0 (updated March 2011). Cochrane Collaboration, 2011. www.cochrane-handbook. org.

63 Viechtbauer W. Conducting meta-analyses in R with the metaphor package. J Stat Soft 2010;36:1-48

64 Khin Maung U, Bolin TD, Duncombe VM, Pereira SP, Myo-Khin, Nyunt-Nyunt-Wai, et al. Effect of short-term intermittent antibiotic treatment on growth of Burmese (Myanmar) village children. Lancet 1990;336:1090-3.

65 Bhatnagar S, Bhan MK, Sazawal S, Gupta U, George C, Arora NK, et al. Efficacy of massive dose oral gentamicin therapy in nonbloody persistent diarrhea with associated malnutrition. J Pediatr Gastroenterol Nutr 1992;15:117-24.

66 Bahl R, Bhandari N, Bhan MK, Saxena M, Bagati A. Efficacy of antimicrobial treatment in non-dysenteric persistent diarrhoea in a community setting. Acta Paediatrica 1996;85:1290-4.

67 Loughlin FH, Alcinidor L, Joseph AA. Extended low-level dosage of oxytetracycline. Antibiotics Ann 1957-58;5:95-8.
68 Lopriore C, Guidoum Y, Briend A, Branca F. Spread fortified with vitamins and minerals induces catch-up growth and eradicates severe anemia in stunted refugee children aged 3-6y. Am J Clin Nutr 2004;80:973-81.

69 Garcia de Olarte D, Trujillo H, Agudelo N, Nelson JD, Haltalin KC. Treatment of diarrhea in malnourished infants and children. A double-blind study comparing ampicillin and placebo. Am J Dis Child 1974;127:379-88.

70 Roy SK, Islam A, Ali R, Islam KE, Khan RA, Ara SH, et al. A randomized clinical trial to compare the efficacy of erythromycin, ampicillin and tetracycline for the treatment of cholera in children. Trans R Soc Trop Med Hyg 1998:92:460-2.

71 Scrimshaw NS, Guzman MA. Effect of dietary supplements and the administration of vitamin B12 and aureomycin on the growth of school children. Bol Oficina Sanit Panam 1953;34:551-62.

72 Wolfsdorf J, Myer EC. Trimethoprim-sulphonamide mixture in the treatment of infantile gastro-enteritis. S Afr Med J 1973:47:1887-9.

73 Trehan I, Shulman RJ, Ou CN, Maleta K, Manary MJ. A randomized, double-blind, placebo-controlled trial of rifaximin, a nonabsorbable antibiotic, in the treatment of tropical enteropathy. Am J Gastroenterol 2009;104:2326-33.

74 World Health Organization Multicentre Growth Reference Study Group. WHO child growth standards based on length/height, weight and age. Acta Paediatr Supp/ 2006;450:76-85.

75 Greenland S, O'Rourke K. Meta-analysis. In: Rothman KJ, Greenland S, Lash TL, eds. Modern epidemiology. Lippincott Williams and Wilkins, 2008:652-82.

76 Francois F, Roper J, Joseph N, Pei Z, Chhada A, Shak JR, et al. The effect of H. pylori eradication on meal-associated changes in plasma ghrelin and leptin. BMC Gastroenterol 2011;11:37.

77 Angelakis E, Merhej V, Raoult D. Related actions of probiotics and antibiotics on gut microbiota and weight modification. Lancet Infect Dis 2013:13:889-99.

78 Gueimonde M, Collado MC. Metagenomics and probiotics. Clin Microbiol Infect 2012;18:32-4.

79 Million M, Lagier JC, Yahav D, Paul M. Gut bacterial microbiota and obesity. Clin Microbio/ Infect 2013;19:305-13.

80 Gerber GK, Onderdonk AB, Bry L. Inferring dynamic signatures of microbes in complex host ecosystems. PLoS Comput Biol 2012;8:e1002624.

81 Smith MI, Yatsunenko T, Manary MJ, Trehan I, Mkakosya R, Cheng J, et al. Gut microbiomes of Malawian twin pairs discordant for kwashiorkor. Science 2013;339:548-54.

82 Ridaura VK, Faith JJ, Rey FE, Cheng J, Duncan AE, Kau AL, et al. Gut microbiota from twins discordant for obesity modulate metabolism in mice. Science 2013;341:1079-89.

83 World Health Organization and United Nations Children's Fund. Co-trimoxazole prophylaxis for HIV-exposed and HIV-infected infants and children: practical approaches to implementation and scale up. 2012. www.unicef.org/aids/files/CotrimoxazoleGuide_2009. pdf.

84 Alcoba G, Kerac M, Breysse S, Salpeteur C, Galetto-Lacour A, Briend A, et al. Do children with uncomplicated severe acute malnutrition need antibiotics? A systematic review and meta-analysis. PLoS One 2013;8:e53184.

85 Scrimshaw NS, Guzmán MA, Flores M, Gordon JE. Nutrition and infection field study in Guatemalan villages, 1959-64. V. Disease incidence among preschool children under natural village conditions, with improved diet and with medical and public health services. Arch Environ Health 1968;16:223-4

\section{Accepted: 17 March 2014}

\section{Cite this as: BMJ 2014;348:g2267}

This is an Open Access article distributed in accordance with the Creative Commons Attribution Non Commercial (CC BY-NC 3.0) license, which permits others to distribute, remix, adapt, build upon this work non-commercially, and license their derivative works on different terms, provided the original work is properly cited and the use is non-commercial. See: http://creativecommons.org/licenses/by-nc/3.0/. 


\section{Tables}

\begin{tabular}{|c|c|c|c|c|c|c|}
\hline \multirow[b]{2}{*}{ Study, country } & \multirow{2}{*}{$\begin{array}{l}\text { Indication for } \\
\text { treatment }\end{array}$} & \multirow[b]{2}{*}{ Eligibility criteria } & \multirow{2}{*}{$\begin{array}{l}\text { Baseline nutritional } \\
\text { status }\end{array}$} & \multicolumn{3}{|c|}{ Intervention } \\
\hline & & & & Antibiotic & Control & Concurrent \\
\hline $\begin{array}{l}\text { Scrimshaw et al } \\
1953^{71} \text {, Guatemala }\end{array}$ & Malnutrition & Schoolchildren & $\begin{array}{l}\text { Children in participating } \\
\text { communities averaged 2-4 } \\
\text { years below US reference } \\
\text { for height and weight }\end{array}$ & Aureomycin & Placebo & $\begin{array}{l}\text { Enriched soya milk } \\
\text { powder given } 6 \\
\text { days/week except } \\
\text { during holidays }\end{array}$ \\
\hline $\begin{array}{l}\text { Guzman et al } \\
1958^{59} \text {, Guatemala }\end{array}$ & Malnutrition & Schoolchildren & $\begin{array}{l}\text { Children in participating } \\
\text { communities averaged } 2-4 \\
\text { years below US reference } \\
\text { for height and weight }\end{array}$ & Aureomycin or penicillin & Placebo & None \\
\hline $\begin{array}{l}\text { Wolfsdorf et al } \\
1973^{72}, \text { South } \\
\text { Africa }\end{array}$ & $\begin{array}{l}\text { Diarrhoea with } \\
\text { or without } \\
\text { vomiting }\end{array}$ & $\begin{array}{l}\text { Infants presenting with diarrhoea } \\
\text { or vomiting severe enough to } \\
\text { warrant hospital stay }\end{array}$ & Not recorded & Trimethoprim-sulphonamide & Placebo & $\begin{array}{l}\text { "Routine" treatment } \\
\text { regimens carried out }\end{array}$ \\
\hline $\begin{array}{l}\text { Gupta et al } 1982^{58}, \\
\text { Guatemala }\end{array}$ & Giardia lamblia & Children & $\begin{array}{l}\text { Mean percentage height } \\
\text { and weight for age: } 88.6 \% \\
\text { and } 71.5 \%\end{array}$ & Metronidazole & Placebo & None \\
\hline $\begin{array}{l}\text { Heikens et al } \\
1993^{56} \text {, Jamaica }\end{array}$ & Malnutrition & $\begin{array}{l}\text { Children malnourished according } \\
\text { to Wellcome classification, } \\
\text { excluding children with oedema, } \\
\text { congenital abnormality, infection } \\
\text { requiring hospital stay, or } \\
\text { anorexia preventing normal home } \\
\text { feeding }\end{array}$ & $\begin{array}{l}\text { Mean percentage height } \\
\text { and weight for age: } 88.6 \% \\
\text { and } 65.1 \%\end{array}$ & Metronidazole & None & $\begin{array}{l}\text { Multivitamins and folic } \\
\text { acid, outpatient } \\
\text { treatment of infection } \\
\text { or illness, advice on } \\
\text { breast feeding and } \\
\text { weaning for duration of } \\
\text { follow-up }\end{array}$ \\
\hline $\begin{array}{l}\text { Tahan et al } 2007^{33} \text {, } \\
\text { Brazil }\end{array}$ & Diarrhoea & $\begin{array}{l}\text { Infants with diarrhoea for at least } \\
7 \text { days who needed hospital stay, } \\
\text { excluding infants with associated } \\
\text { disorders, use of antibiotics in } \\
\text { preceding } 7 \text { days, or evidence of } \\
\text { systemic infection }\end{array}$ & $\begin{array}{l}\text { Mean height and weight for } \\
\text { age } Z \text { scores: }-2.02 \text { and } \\
-2.36\end{array}$ & Polymixin B & Placebo & None \\
\hline $\begin{array}{l}\text { Goto et al } 2009^{57} \text {, } \\
\text { Bangladesh }\end{array}$ & G lamblia & Infants & $\begin{array}{l}\text { Mean height and weight for } \\
\text { age } Z \text { scores: }-1.05 \text { and } \\
-1.82\end{array}$ & Secnidazole & Placebo & None \\
\hline $\begin{array}{l}\text { Trehan et al } \\
2009^{73}, \text { Malawi }\end{array}$ & $\begin{array}{l}\text { Environmental } \\
\text { enteropathy }\end{array}$ & $\begin{array}{l}\text { Children, excluding those with } \\
\text { chronic debilitating illnesses or } \\
\text { evidence of severe acute } \\
\text { malnutrition }\end{array}$ & $\begin{array}{l}\text { Mean height and weight for } \\
\text { age } Z \text { scores: }-1.67 \text { and } \\
-0.91\end{array}$ & Rifaximin & Placebo & None \\
\hline $\begin{array}{l}\text { Prendergast et al } \\
2011^{35}, \text { Zambia }\end{array}$ & $\begin{array}{l}\text { Prophylaxis } \\
\text { against } \\
\text { opportunistic } \\
\text { infection }\end{array}$ & $\begin{array}{l}\text { Children with positive HIV } \\
\text { antibody test result, excluding } \\
\text { those with opportunistic infection, } \\
\text { life expectancy } \leq 4 \text { weeks, current } \\
\text { cotrimoxazole treatment or } \\
\text { allergy to this drug, or previous } \\
\text { Pnuemocystis jirovecii } \\
\text { pneumonia }\end{array}$ & $\begin{array}{l}\text { Mean height and weight for } \\
\text { age } Z \text { scores: }-3.55 \text { and } \\
-3.10 \\
\end{array}$ & Cotrimoxazole & Placebo & None \\
\hline $\begin{array}{l}\text { Trehan et al } \\
2013^{34} \text {, Malawi }\end{array}$ & $\begin{array}{l}\text { Severe acute } \\
\text { malnutrition }\end{array}$ & $\begin{array}{l}\text { Children with oedema, or weight } \\
\text { for height } Z \text { score } \leq 3\end{array}$ & $\begin{array}{l}\text { Mean height for age } Z \text { score } \\
\text { was }-3.19\end{array}$ & Amoxicillin or cefdinir & Placebo & $\begin{array}{l}\text { Standardised nutrition } \\
\text { counselling and ready } \\
\text { to use therapeutic food } \\
\text { at dose of } \\
\text { approximately } 175 \\
\mathrm{kcal} / \mathrm{kg} / \text { day given in } 2 \\
\text { week intervals }\end{array}$ \\
\hline
\end{tabular}


Table 2| Growth outcomes and potential treatment effect moderators in randomised controlled trials of antibiotic use and growth in prepubertal children included in meta-analysis

\begin{tabular}{|c|c|c|c|c|c|c|c|c|c|c|c|c|}
\hline \multirow[b]{3}{*}{ Study } & \multirow[b]{3}{*}{ IPD } & \multirow{3}{*}{$\begin{array}{l}\text { Mean } \\
\text { (SD) age } \\
\text { (months) }\end{array}$} & \multirow{3}{*}{$\begin{array}{c}\text { No }(\%) \\
\text { male }\end{array}$} & \multicolumn{4}{|c|}{ Antibiotics } & \multirow{3}{*}{$\begin{array}{l}\text { Mean } \\
\text { follow-up } \\
\text { (days) }\end{array}$} & \multicolumn{4}{|c|}{ Mean growth/month of follow-up } \\
\hline & & & & \multirow{2}{*}{$\begin{array}{l}\text { Class, } \\
\text { spectrum }\end{array}$} & \multirow[b]{2}{*}{ Dosage } & \multirow[b]{2}{*}{ Doses/day } & \multirow{2}{*}{$\begin{array}{c}\text { Days } \\
\text { treated }\end{array}$} & & \multicolumn{2}{|c|}{ Height (cm) } & \multicolumn{2}{|c|}{ Weight (g) } \\
\hline & & & & & & & & & Controls & Treated & Controls & Treated \\
\hline 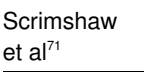 & No & $\begin{array}{l}114.9 \\
\left(\mathrm{NR}^{\star}\right)\end{array}$ & $\begin{array}{c}143 \\
(57.2)^{\star}\end{array}$ & $\begin{array}{l}\text { Bacteriostatic, } \\
\text { broad spectrum }\end{array}$ & $50 \mathrm{mg}$ & 1 & $667 \dagger$ & 758 & 0.39 & 0.42 & 180.0 & 270.0 \\
\hline $\begin{array}{l}\text { Guzman et } \\
\left.a\right|^{59}\end{array}$ & No & $114.9(\mathrm{NR})$ & $143(57.2)$ & $\begin{array}{l}\text { Bacteriostatic, } \\
\text { broad spectrum }\end{array}$ & $50 \mathrm{mg}$ & 1 & $394 \dagger$ & 394 & 0.36 & 0.36 & 170.0 & 166.0 \\
\hline $\begin{array}{l}\text { Wolfsdorf et } \\
\mathrm{al}^{72}\end{array}$ & No & $5.9(6.4)$ & NR & $\begin{array}{l}\text { Bactericidal, } \\
\text { broad spectrum }\end{array}$ & NR & NR & NR & 91 & NR & NR & 664.0 & 788.4 \\
\hline Gupta et al ${ }^{58}$ & No & $\begin{array}{c}23.0 \\
(17.2 \ddagger)\end{array}$ & NR & $\begin{array}{l}\text { Bactericidal, } \\
\text { narrow spectrum }\end{array}$ & $25 \mathrm{mg} / \mathrm{kg}$ & 2 & 42 & NR & 0.51 & 0.58 & 135.9 & 154.2 \\
\hline $\begin{array}{l}\text { Heikens et } \\
\mathrm{al}^{56}\end{array}$ & No & $14.1(6.5)$ & $\mathrm{NR}$ & $\begin{array}{l}\text { Bactericidal, } \\
\text { narrow spectrum }\end{array}$ & $20 \mathrm{mg} / \mathrm{kg}$ & 1 & 5 & 179 & 12.40 & 12.20 & 1336.7 & 1393.3 \\
\hline Tahan et $\mathrm{al}^{33}$ & Yes & $4.0(2.0)$ & $17(68.0)$ & $\begin{array}{l}\text { Bactericidal, } \\
\text { narrow spectrum }\end{array}$ & $2.5 \mathrm{mg} / \mathrm{kg}$ & 4 & 7 & 7 & $N R$ & $N R$ & $710.5 \S$ & $735.7 \S$ \\
\hline Goto et $\mathrm{al}^{57}$ & Yes & $8.6(3.2)$ & $135(50.4)$ & $\begin{array}{l}\text { Bactericidal, } \\
\text { narrow spectrum }\end{array}$ & $35 \mathrm{mg} / \mathrm{kg}$ & 1 & 10 & 264 & 9.11 & 9.12 & 1105.1 & 1100.7 \\
\hline $\begin{array}{l}\text { Trehan et } \\
\mathrm{al}^{73}\end{array}$ & Yes & $47.2(7.12)$ & $60(41.7)$ & $\begin{array}{l}\text { Bacteriostatic, } \\
\text { broad spectrum }\end{array}$ & $10 \mathrm{mg}$ & 2 & 7 & 28 & $107.56 \mathbb{I}$ & $107.96 \mathbb{I}$ & $14957.1 \rrbracket$ & 15030.39 \\
\hline $\begin{array}{l}\text { Prendergast } \\
\text { et } \mathrm{al}^{35}\end{array}$ & Yes & $64.5(44.7)$ & $266(49.2)$ & $\begin{array}{l}\text { Bactericidal, } \\
\text { broad spectrum }\end{array}$ & $\begin{array}{c}240 \mathrm{~g}(<5 \\
\mathrm{yrs}) ; 480 \mathrm{~g} \\
(>5 \mathrm{yrs})\end{array}$ & 1 & 575 & 575 & 5.66 & 5.77 & 803.9 & 845.0 \\
\hline $\begin{array}{l}\text { Trehan et } \\
\mathrm{al}^{34}\end{array}$ & Yes & $21.1(9.1)$ & $\begin{array}{c}1317 \\
(47.6)\end{array}$ & $\begin{array}{l}\text { Bactericidal, } \\
\text { broad spectrum }\end{array}$ & $\begin{array}{c}7 \mathrm{mg} / \mathrm{kg} \\
\text { (cefdinir); } \\
40-45 \mathrm{mg} / \mathrm{kg} \\
\text { (amoxicillin) }\end{array}$ & 2 & 7 & 43 & 26.74 & 26.76 & 2898.0 & 2938.9 \\
\hline
\end{tabular}

IPD=individual patient data; $N R=$ not reported.

*Not reported by Schrimshaw et al. ${ }^{71}$ Values assumed to be same as in Guzman et $a^{59}$ as both studies were conducted in communities in Guatemalan highlands in 1950 s by same research group and recruited children in 5-12 year age range.

†Estimated from mean number of treatment days reported per trial arm.

$\ddagger$ Not reported by Gupta et al, ${ }^{58}$ estimated from Schrimshaw et al $1968 .{ }^{85}$

$\S M e a n$ change in weight per day; follow-up was seven days.

IFollow-up was 28 days; these represent height and weight at end of follow-up. 
Table 3| Estimated average differences in antibiotic treatment effects on growth in prepubertal children, using weighted bivariate random effects metaregression

\begin{tabular}{|c|c|c|c|c|c|c|c|c|}
\hline \multirow[b]{2}{*}{ Trial characteristics } & \multirow[b]{2}{*}{ No } & \multicolumn{3}{|c|}{ Height (cm/month) } & \multirow[b]{2}{*}{ No } & \multicolumn{3}{|c|}{ Weight (g/month) } \\
\hline & & $\begin{array}{c}\text { Mean } \\
\text { difference }\end{array}$ & $P$ value & $\mathrm{I}^{2}(\%)(95 \% \mathrm{Cl})$ & & $\begin{array}{c}\text { Mean } \\
\text { difference }\end{array}$ & $P$ value & $\mathrm{I}^{2}(\%)(95 \% \mathrm{Cl})$ \\
\hline $\begin{array}{l}\text { Geographical region (Africa } v \\
\text { other) }\end{array}$ & 8 & 0.05 & 0.275 & 79.6 (39.7 to 98.8$)$ & 10 & 35.57 & 0.002 & 50.9 (10.6 to 99.1$)$ \\
\hline Publication year & 8 & 0.00 & 0.650 & 78.7 (35.5 to 99.0$)$ & 10 & 0.50 & 0.275 & 77.6 (47.1 to 99.9$)$ \\
\hline $\begin{array}{l}\text { Treatment effect adjusted for } \\
\text { baseline imbalances (yes } v \text { no) }\end{array}$ & 8 & 0.00 & 0.964 & 88.5 (55.9 to 99.9$)$ & 10 & -17.59 & 0.465 & 85.4 (62.8 to 99.9$)$ \\
\hline Mean length of follow-up (days) & 7 & 0.00 & 0.282 & 79.8 (35.3 to 99.4$)$ & 9 & -0.05 & 0.490 & 87.5 (61.1 to 99.9$)$ \\
\hline No of doses/day & 8 & 0.02 & 0.648 & $83.4(44.1$ to 98.8$)$ & 9 & 21.70 & 0.307 & 84.4 (56.9 to 99.7$)$ \\
\hline Duration of treatment (days) & 8 & 0.00 & 0.340 & $81.9(47.1$ to 99.1$)$ & 9 & 0.00 & 0.921 & 86.6 (65.6 to 99.9$)$ \\
\hline $\begin{array}{l}\text { Antibiotic class (bactericidal } v \\
\text { bacteriostatic) }\end{array}$ & 7 & -0.05 & 0.792 & 71.6 (25.9 to 99.6 ) & 8 & -51.61 & 0.727 & 87.1 (72.1 to 100.0$)$ \\
\hline $\begin{array}{l}\text { Antibiotic spectrum (broad } v \\
\text { narrow) }\end{array}$ & 8 & 0.02 & 0.666 & 89.2 (57.2 to 99.3$)$ & 10 & 9.41 & 0.666 & 84.6 (61.0 to 99.9$)$ \\
\hline $\begin{array}{l}\text { Participants given concurrent } \\
\text { nutritional intervention (yes } v \text { no) }\end{array}$ & 8 & -0.05 & 0.356 & 82.5 (44.9 to 98.6 ) & 10 & 31.00 & 0.110 & 75.7 (44.2 to 99.9$)$ \\
\hline Mean age (months) & 8 & 0.00 & 0.948 & 82.0 (1.7 to 96.7$)$ & 10 & -0.24 & 0.381 & 82.0 (54.3 to 99.9) \\
\hline $\begin{array}{l}\text { Treatment was for malnutrition } \\
\text { (yes } v \text { no) }\end{array}$ & 8 & -0.06 & 0.066 & 75.2 (17.4 to 99.0$)$ & 10 & 2.65 & 0.906 & 85.1 (62.5 to 99.9$)$ \\
\hline $\begin{array}{l}\text { Treatment was for Giardia } \\
\text { lamblia infection (yes } v \text { no) }\end{array}$ & 8 & 0.01 & 0.833 & 88.6 (56.2 to 99.4$)$ & 10 & -26.42 & 0.210 & 82.2 (55.1 to 99.9$)$ \\
\hline $\begin{array}{l}\text { Treatment was for diarrhoea with } \\
\text { or without vomiting (yes } v \text { no) } \dagger\end{array}$ & NA & NA & NA & NA & 10 & 144.37 & 0.075 & 85.3 (60.9 to 99.8$)$ \\
\hline
\end{tabular}

$\mathrm{NA}=$ not applicable.

${ }^{*}$ Excludes Prendergast et $\mathrm{al}^{35}$ and Wolfsdorf et $\mathrm{al}^{72}$ as not clear whether trimethoprim with sulphonamide or sulfamethoxazole are bacteriostatic or bactericidal in combination.

†No trials reporting height treated participants for diarrhoea with or without vomiting. 
Table 4| Significant moderators of antibiotic treatment effects on growth in prepubertal children, using weighted random effects metaregression adjusted for mean study population age

\begin{tabular}{|c|c|c|c|}
\hline Trial characteristics & No & Mean difference $(95 \% \mathrm{Cl})$ & $\mathrm{I}^{2}(\%)(95 \% \mathrm{Cl})$ \\
\hline \multicolumn{4}{|l|}{ Height model 1 (cm/month): } \\
\hline Duration of treatment (days) & 8 & $0.007(0.00$ to 0.01$)$ & \multirow[t]{2}{*}{53.6 (0.0 to 99.3$)$} \\
\hline Mean age (months) & 8 & $-0.001(-0.002$ to 0.00$)$ & \\
\hline \multicolumn{4}{|l|}{ Weight model 1 (g/month): } \\
\hline Geographical region (Africa $v$ other) & 10 & 33.2 (5.3 to 61.2$)$ & \multirow[t]{2}{*}{53.5 (3.6 to 99.9$)$} \\
\hline Mean age (months) & 10 & $-0.2(-0.4$ to -0.1$)$ & \\
\hline \multicolumn{4}{|l|}{ Weight model 2 (g/month) } \\
\hline Treatment was for Giardia lamblia (yes $v$ no) & 10 & $-46.9(-83.2$ to -10.6$)$ & \multirow[t]{2}{*}{57.8 (9.3 to 99.9$)$} \\
\hline Mean age (months) & 10 & $-0.5(-1.0$ to -0.1$)$ & \\
\hline
\end{tabular}




\section{Figures}

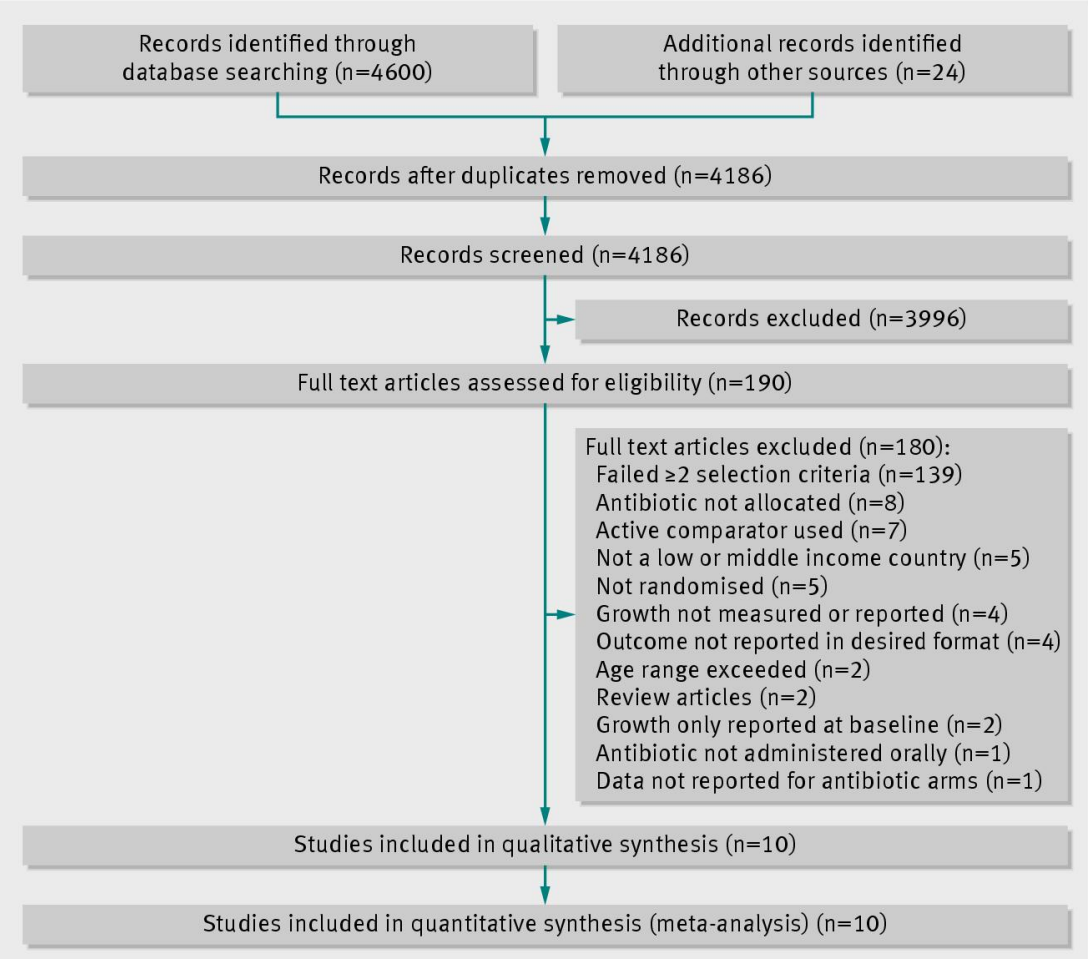

Fig 1 Flow diagram of search retrieval and trial selection

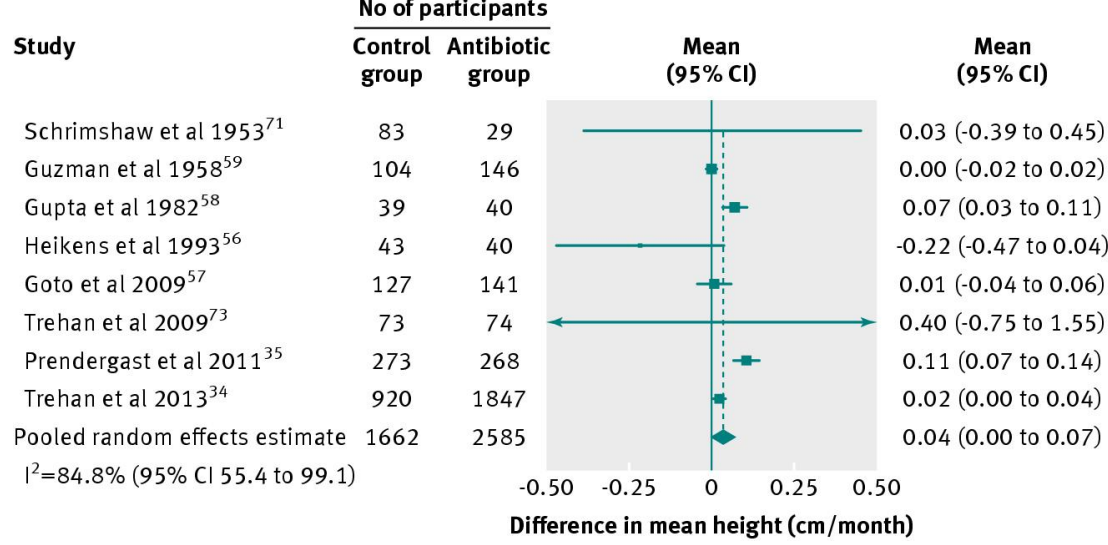

Fig 2 Random effects meta-analyses and forest plots of antibiotic use and height. Point size reflects study weight 


\section{Study}

Schrimshaw et al $1953^{71}$

Guzman et al $1958^{59}$

Wolfsdorf et al $1973^{72}$

Gupta et al $1982^{58}$

Heikens et al $1993^{56}$

Tahan et al $2007^{33}$

Goto et al $2009^{57}$

Trehan et al $2009^{73}$

Prendergast et al $2011^{35}$

Trehan et al $2013^{34}$

Pooled random effects estimate

$\mathrm{I}^{2}=84.4 \%(95 \% \mathrm{Cl} 63.3$ to 99.9$)$

\section{No of participants}

\section{Control Antibiotic}

group group

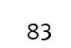

83

29

104
26

39

43

11

127

1699

9

18

40

40

14

141

74

268

1847

2617

Mean

$\begin{array}{lllll}-800 & -400 & 0 & 400 \quad 800\end{array}$

Difference in mean weight ( $\mathrm{g} / \mathrm{month})$

Fig 3 Random effects meta-analyses and forest plots of antibiotic use and weight. Point size reflects study weight 